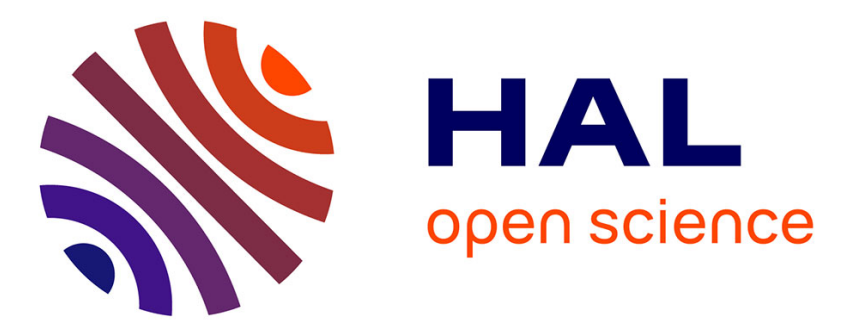

\title{
Multixenobiotic resistance in Mytilus edulis: Molecular and functional characterization of an ABCG2- type transporter in hemocytes and gills
}

Yosra Ben Cheikh, Benoît Xuereb, Céline Boulange-Lecomte, Frank Le Foll

\section{- To cite this version:}

Yosra Ben Cheikh, Benoît Xuereb, Céline Boulange-Lecomte, Frank Le Foll. Multixenobiotic resistance in Mytilus edulis: Molecular and functional characterization of an ABCG2- type transporter in hemocytes and gills. Aquatic Toxicology, 2017, 195, pp.88-96. 10.1016/j.aquatox.2017.12.012 . hal-01755816

HAL Id: hal-01755816

https://hal-normandie-univ.archives-ouvertes.fr/hal-01755816

Submitted on 30 Mar 2018

HAL is a multi-disciplinary open access archive for the deposit and dissemination of scientific research documents, whether they are published or not. The documents may come from teaching and research institutions in France or abroad, or from public or private research centers.
L'archive ouverte pluridisciplinaire HAL, est destinée au dépôt et à la diffusion de documents scientifiques de niveau recherche, publiés ou non, émanant des établissements d'enseignement et de recherche français ou étrangers, des laboratoires publics ou privés. 
1 Multixenobiotic resistance in Mytilus edulis: molecular and functional characterization of

2 an ABCG2- type transporter in hemocytes and gills

3 Yosra Ben Cheikh ${ }^{\mathrm{a}}$, Benoit Xuereb ${ }^{\mathrm{a}}$, Céline Boulangé-Lecomte ${ }^{\mathrm{a}}$ and Frank Le Foll ${ }^{\mathrm{a}}$

4

$5 \quad$ Authors affiliation

6 aUniversity of Le Havre Normandy, Environmental Stress and Aquatic Biomonitoring, UMR-

7 I 02 SEBIO, 25 rue Philippe Lebon, F-76063 Le Havre, France

8

9

10

Corresponding Author

12

Yosra Ben Cheikh

13

E-mail: yosra_bencheikh@yahoo.fr

Tel +33(0)2 32744379

15

16

17

18

19

20

21

22

23

24

25

26 


\section{Abstract}

Among the cellular protection arsenal, ABC transporters play an important role in xenobiotic efflux in marine organisms. Two pumps belonging to B and C subfamily has been identified in Mytilus edulis. In this study, we investigated the presence of the third major subtype ABCG2/BCRP protein in mussel tissues. Transcript was expressed in hemocytes and with higher level in gills. Molecular characterization revealed that mussel ABCG2 transporter share sequence and organizational structure with mammalian and molluscan orthologs. Overall identity of the amino acid sequence with corresponding homologs from other organisms was comprised between $49 \%$ and $98 \%$. Furthermore, protein efflux activity was demonstrated using a combination of fluorescent allocrites and specific inhibitors. The accumulation of bodipy prazosin and pheophorbide A was heterogeneous in gills and hemocytes. Most of the used blockers enhanced probe accumulation at different levels, more significantly for bodipy prazosin. Moreover, Mrp classical blocker MK571 showed a polyspecificity.

In conclusion, our data demonstrate that several $\mathrm{ABC}$ transporters contribute to MXR phenotype in the blue mussel including ABCG2 that form an active pump in hemocytes and gills. Efforts are needed to distinguish between the different members and to explore their single function and specificity towards allocrites and chemosensitizers.

Keywords: ABC transporter, efflux activity, blue mussel, invertebrates

(1)

(1)

\section{.}




\section{Introduction}

The aquatic environment is polluted by a variety of chemical compounds and heavy metals released by urban communities and industrial plants. Many of these xenobiotics are known to be a threat to most marine species health due to their environmental persistence, bioaccumulation in various tissues and intrinsic toxicity (Anita H Poulsen, 2012; Giarratano et al., 2010). Bivalves of the genus Mytilus are of particular interest because of their resistance to chemical contaminants. These bioindicator species are therefore used as sentinel organisms. Immunological responses mediated by hemocytes are frequently investigated to monitor biological effects of water pollution (Akaishi et al., 2007; Auffret et al., 2006; Gupta and Singh, 2011).

In order to survive, marine organisms have developed strategies to overcome adverse effects of pollutants. Bivalves can limit their exposure to toxic compounds using behavioural responses such as shell closure and restriction of filtration rate (Haberkorn et al., 2011; Hégaret et al., 2007). Furthermore, they possess multiple cellular detoxification mechanisms that can influence the uptake, distribution and elimination of xenobiotics (Farris and Hassel, 2006). Among the arsenal of enzymes involved in animal cell detoxification, some members of the ATP Binding Cassette (ABC) superfamily are found (Bard, 2000; Luckenbach et al., 2008; Rioult et al., 2014).

ABC transporters were first described for their role in multidrug resistance (MDR) to chemotherapeutic drugs (Gottesman and Ling, 2006; Nielsen and Skovsgaard, 1992; Sharom, 2008). These ATP-powered transmembrane proteins found in tumor cells of mammals are one of the major cause of chemotherapeutic failure in cancer therapy. They actively pump out of the cytosol into the external medium a multitude of distinct cytotoxic compounds (Kathawala et al., 2015). Similarly to this efflux-based drug resistance, a xenobiotic transport mediated by $\mathrm{ABC}$ proteins was demonstrated for the first time in fresh water mussels as a strategy to defense against pollutants (Kurelec, 1992; Kurelec and Pivcević, 1989). Considering the variety of chemically unrelated compounds carried by this system, Kurelec coined the term of Multixenobiotic Resistance (MXR) by analogy to the MDR phenotype (Kurelec, 1992). In marine organisms, ATP-fueled pumps act as a first line of defense, preventing toxic chemicals from entering the cell. Secondarily, if toxicants even enter the cytoplasm, ABC transporters can be the last protection by expelling the toxicants and associated metabolites (Epel et al., 2008). The MXR phenotype is supposedly ubiquitous in aquatic invertebrates. Functional and molecular assays allowed the identification and characterization of some $\mathrm{ABC}$ transporters 
members in several species including sponges (Kurelec et al., 1992), innkeeper worms (Toomey and Epel, 1993), molluscs (Faria et al., 2011; Luckenbach and Epel, 2008; McFadzen et al., 2000; Navarro et al., 2012; Rioult et al., 2014) and crabs (Köhler et al., 1998; Minier et al., 2008).

The three major types of MDR proteins in humans include members of the ABCB, the ABCC and the ABCG2 subfamilies (Sarkadi et al., 2006). In marine invertebrates, only ABCB and $\mathrm{ABCC}$ transporters have been well described. Two complete sequences analog to $\mathrm{ABCB} / \mathrm{P}-$ glycoprotein (P-gp) and ABCC/MDR-related protein (MRP) subfamilies were identified in Californian mussel (Luckenbach and Epel, 2008). Furthermore, efflux activities have been confirmed using functional efflux assays with substrates and inhibitors (Luckenbach et al., 2008; Luckenbach and Epel, 2008). Similarly, P-gp transcript as well as pump activity were characterized in the Asian green mussel Perna viridis (Huang et al., 2014). In Mytilus edulis, Luedeking and co-authors obtained fragments of abcb and abcc sequences in various tissues and MXR transcript levels were measured in gills, mantle and digestive gland (Luedeking et al., 2005; Luedeking and Koehler, 2002). Lately, ABCC/MRP transporter was detected in blue mussel hemocytes. Authors demonstrated that pump activity was principally supported by the hemocyte subpopulation eosinophilic granulocytes (Rioult et al., 2014). To our knowledge, only few studies explored the presence of ABCG2/BCRP transporter in bivalves. Protein and gene expression were quantified respectively in the Indian rock oyster Saccostrea forskali (Kingtong et al., 2007) and the Asian clam Corbicula fluminea (Chen et al., 2015).

In this study, we investigate the existence of the third major type of MDR proteins ABCG2 in blue mussel hemocytes and gills. Complete ABCG2 amino acid sequence was identified and characterized. Therefore, ABCG2 gene expression was quantified and transcript levels were compared in mussel tissues. For determining whether ABCG2 transporter is active in M. edulis hemocyte subpopulations and gills, dye efflux assays were performed using fluorescent substrates combined with specific blockers.

\section{Material and methods}

\subsection{Chemicals}

Bodipy prazosin (Invitrogen Life technologies) and pheophorbide A (Sigma Aldrich) were used as fluorescent dyes and substrates of BCRP. Inhibitors of $\mathrm{ABC}$ transporters described in Table 1 were purchased from Sigma Aldrich and Tebu-bio for Ko134. 


\subsection{Mussel and tissue collection}

Adult mussels, M. edulis with shell length ranging from 4 to $5 \mathrm{~cm}$, were collected on the

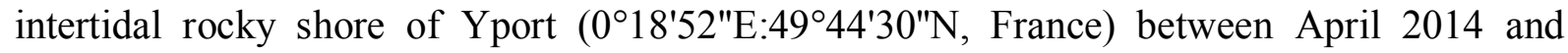
December 2015, immediately transported to the laboratory and placed in a temperaturecontrolled $\left(10^{\circ} \mathrm{C}\right)$ aerated Biotop Nano Cube 60 seawater tank (Sera, Heinsberg, Germany), equipped with mechanical and activated biological filtering. The animals were fed with algae (Isochrysis galbana) and maintained in these conditions for at least one week before use.

Hemolymph was withdrawn from the posterior adductor muscle sinus, by gentle aspiration with a $1 \mathrm{~mL}$ syringe equipped with a $22 \mathrm{G}$ needle. For RNA extraction, pooled aliquots from 10 mussels were centrifuged $5 \mathrm{~min}$ at $1200 \mathrm{~g}$. Gills were gently removed from mussel and immediately used in RNA extraction. For efflux activity assays, tissues were kept entire or excised using biopsy punches (6 $\mathrm{mm}$ diameter) to obtain disks.

\subsection{RNA extraction and cDNA synthesis}

Total RNA was isolated from hemocytes or from gills using RNeasy mini kit (Qiagen) according to the manufacture's recommendations. RNA suspensions were treated with DNase (Turbo DNA free kit, Ambion) for genomic DNA removal. Total RNA concentration was analyzed by spectrophotometry (Nanodrop, Thermo Scientific). RNA integrity was checked by electrophoresis on $1 \%$ agarose gel with SYBR staining (SYBR Safe DNA gel stain, Invitrogen). Reverse transcription was carried from total RNA (1 $\mu \mathrm{g})$ using M-MLV RNAse H minus (100U, Promega) and oligo $(\mathrm{dT})_{20}(1 \mu \mathrm{g})$ in the presence of Recombinant RNasin ${ }^{\circledR}$ Ribonuclease Inhibitor (80U, Promega). Complementary first-strand DNA (cDNA, $40 \mu \mathrm{L}$ ) were diluted in $60 \mu \mathrm{L}$ of ultra-pure water and stored in $5 \mu \mathrm{L}$ aliquots at $-20^{\circ} \mathrm{C}$ until use.

\subsection{Gene fishing and analysis of transporter sequence}

The primers used in gene fishing were directed against sequence of abcg2 ortholog from Mytilus galloprovincialis (Genbank accession number gi|406717747) and designed using Primer3 software (http://bioinfo.ut.ee/primer3-0.4.0/, Table 2). PCR was performed on cDNA gills using Taq'Ozyme purple mix (Ozyme). After an initial denaturation step at $95^{\circ} \mathrm{C}$ for $2 \mathrm{~min}, 45$ cycles were performed including a denaturation step at $95^{\circ} \mathrm{C}$ for $30 \mathrm{~s}$, annealing at $62^{\circ} \mathrm{C}$ for 30 $\mathrm{s}$ and extension at $72^{\circ} \mathrm{C}$ for $1 \mathrm{~min}$. The final extension step was continued for $5 \mathrm{~min}$. The amplified PCR products were purified from 1.2\% agarose gel using QIAquick gel extraction kit (Qiagen). Partial cDNA sequences were obtained after sequencing and blasted with abcg2 cDNA from other organisms to verify the homology (https://blast.ncbi.nlm.nih.gov/Blast.cgi). 
The 5' cDNA of Mytilus edulis abcg2 was obtained by 5'RACE PCR using SMART RACE cDNA amplification kit (Clontech) according to the user's manual. The 5'RACE product was amplified by PCR using gene specific primer (Table 2) and universal primer mix supplied with the RACE PCR kit. PCR was performed in a touchdown mode: 5 cycles at $94{ }^{\circ} \mathrm{C}(30 \mathrm{~s}) / 72^{\circ} \mathrm{C}(3$ min), 5 cycles $94^{\circ} \mathrm{C}(30 \mathrm{~s}) / 70^{\circ} \mathrm{C}(30 \mathrm{~s}) / 72^{\circ} \mathrm{C}(3 \mathrm{~min})$ and 25 cycles $94^{\circ} \mathrm{C}(30 \mathrm{~s}) / 68^{\circ} \mathrm{C}(30 \mathrm{~s}) / 72^{\circ} \mathrm{C}$ (3 min). Amplified products were gel purified, cloned and sequenced. The resulting PCR and RACE PCR sequences were assembled using Geneious R7.1.9 software. In order to get the whole open reading frame and to confirm assembled sequences, a PCR reaction was performed using primers directed against Mytilus edulis abcg2 (Table 2) following the same cycling conditions cited previously.

Final sequence was analyzed using tools at expasy (http://web.expasy.org/), NCBI (http://www.ncbi.nlm.nih.gov/) and cbs server (http://www.cbs.dtu.dk/services/). Multiple sequence alignment and determinations of identity rates between amino acid sequences of $\mathrm{ABC}$ transporters from different organisms were performed using Clustal W2. Phylogenetic tree was built according to Neighbor-Joining method using Geneious R7.1.9 software.

\subsection{Quantitative real-time polymerase chain reaction}

QPCR analysis was conducted on the Rotor-Gene Q 2- plex HRM (QIAGEN, Courtaboeuf, France) using the QuantiTect ${ }^{\circledR}$ SYBR ${ }^{\circledR}$ Green Master Mix (2X, QIAGEN). Each reaction was run in duplicate with a final volume of $20 \mu \mathrm{L}$ containing $5 \mu \mathrm{L}$ cDNA and $0.5 \mu \mathrm{M}$ of each primer. Specific qPCR primers for abcg2-like and the housekeeping (hk) Elongation factor efl $\alpha$ were designed using ProbeFinder software (https://lifescience.roche.com/, Table 2). The efl $\alpha$ was chosen as hk gene because of its stability from different experimental conditions (Lacroix et al., 2014).

Reactions were initiated with an initial denaturation for $15 \mathrm{~min}$ at $95{ }^{\circ} \mathrm{C}$ followed by 45 cycles at $94{ }^{\circ} \mathrm{C}$ for $15 \mathrm{~s}, 59{ }^{\circ} \mathrm{C}$ for $30 \mathrm{~s}$ and $72{ }^{\circ} \mathrm{C}$ for $6 \mathrm{~s}$. The melting curve was finally determined during a slow temperature elevation from 60 to $95{ }^{\circ} \mathrm{C}\left(1^{\circ} \mathrm{C} \cdot \mathrm{s}^{-1}\right)$. The run included blank controls (water). For the qPCR efficiencies of each primer pair used, standard curves were generated using eight serial dilutions of cDNA (from $10^{9}$ to $10^{1}$ copies) (Xuereb et al., 2012). The level of expression of the target genes, normalized to the efla housekeeping gene, was then calculated using the (1+efficiency $)^{-\Delta \mathrm{Ct}}$ formula. 


\subsection{Analysis of MXR activity}

MXR activity was assessed in hemocytes by flow cytometry and in gills by microplate reader assays using dye efflux assays in absence or presence of inhibitors.

\subsubsection{MXR activity in hemocytes}

Crude hemolymph was placed into individual wells of 24-well tissue-culture plates (Greiner) and cells allowed to adhere for 15 minutes at $15^{\circ} \mathrm{C}$. The hemolymph was removed and replaced with $400 \mu \mathrm{L}$ of marine physiological saline solution (MPSS, $\mathrm{pH} 7.8,0.2 \mu \mathrm{m}$ filtered) alone for the control or containing $\mathrm{ABC}$ transporter inhibitors at $30 \mu \mathrm{M}$ final concentration. After $30 \mathrm{~min}$ of incubation at $15^{\circ} \mathrm{C}$, fluorescent dyes were added: pheophorbide $\mathrm{A}$ at $5 \mu \mathrm{M}$ or bodipy prazosin at $0.5 \mu \mathrm{M}$ and incubated $15 \mathrm{~min}$ at $15^{\circ} \mathrm{C}$. Supernatants were gently aspirated and attached cells were removed by adding cold Alsever's solution $(300 \mathrm{mM} \mathrm{NaCl}, 100 \mathrm{mM}$ Glucose, $30 \mathrm{mM}$ sodium Citrate, $26 \mathrm{mM}$ citric acid, $10 \mathrm{mM}$ EDTA, pH 5.4) and immediately analyzed by Cell Lab Quanta SC MPL flow cytometer (Beckman Coulter).

\subsubsection{MXR activity in gills}

Entire gills or tissue disks obtained by biopsy punches, were placed into individuals wells of 12-well plates (Greiner) or black 96-well plates (nunc) filled with MPSS. ABC transporter inhibitors were added at $30 \mu \mathrm{M}$ and incubated for $30 \mathrm{~min}$ at $15^{\circ} \mathrm{C}$. Thereafter, pheophorbide $\mathrm{A}$ $(5 \mu \mathrm{M})$ or bodipy prazosin $(0.5 \mu \mathrm{M})$ were added for $15 \mathrm{~min}$ at $15^{\circ} \mathrm{C}$. Whole gills or tissue disks were transferred in new wells containing MPSS to remove the probe excess and homogenized by horizontal rotation for $30 \mathrm{~s}$. The fluorescence accumulated was measured with a microplate reader (Tecan, excitation/ emission wavelength in $\mathrm{nm}$ : 490/530 for bodipy prazosin and 395/670 for pheophorbide A).

Mean values of fluorescence measured from biopsies were plotted and compared. A MXR activity factor (MAF) was calculated using the following formula: $100 *\left(\frac{\text { MFL inhibitor - MFL ctrl }}{\text { MFL inhibitor }}\right)$ wherein MFL inhibitor and MFL ctrl are the mean fluorescence intensity values measured in the presence and absence of inhibitor (Lebedeva et al., 2011).

\subsection{Statistical analyses}

Statistical analysis was performed by using SigmaPlot 12 (Systat Software Inc., Chicago, IL). Replicates were averaged and the values were tested for normality (Shapiro-Wilk) and paired comparisons were performed by Student's t-tests. Statistical significance was accepted for $* \mathrm{p}<$ $0.05, * * \mathrm{p}<0.01$ or $* * * \mathrm{p}<0.001$. 


\subsection{Identification and phylogenetic analysis of $\mathrm{ABCG} 2$ transporter}

The expression of ABCG2 gene in Mytilus edulis gills was investigated by RT PCR. The amplified product had the expected size and generated a partial cDNA sequence of $542 \mathrm{pb}$. Blast analysis confirmed that the fragment was a part of an abcg2-like gene sequence.

The $2198 \mathrm{pb}$ full length cDNA sequence was secondarily obtained by assembling of various sequences from RACE and PCR reactions performed on different cDNAs (Genbank accession number KX551963). It contained a 1926 pb ORF encoding a 641 amino acid polypeptide. In addition, $265 \mathrm{pb}$ and $6 \mathrm{pb}$ of 5' -and 3'-UTR were identified. The deduced amino acid sequence has a calculated molecular mass of $71.5 \mathrm{kDa}$ and a theoretical isoelectric point of 7.57.

Analyses of amino acid sequence revealed the structural organization of ABCG2 transporter in a single subunit with a nucleotide binding domain (NBD) and a membrane spanning domain (MSD). The NBD contained highly conserved motifs of ABC transporters: the walker A/Ploop, walker B, ABC signature (C motif) as well as the Q-loop/lid upstream of the walker A and the D-loop and H-loop/switch regions downstream of the walker B (Figure 1-2). Furthermore, the MSD was organized in six putative transmembrane helices and the $\mathrm{NH}_{2}$ terminal was located in the cytosol. Two possible N-glycosylation sites (Asn-Val-Ser) were identified respectively in the $2^{\text {nd }}-3^{\text {rd }}$ (amino acid 454-456) and the $5^{\text {th }}-6^{\text {th }}$ (amino acid 552-554) transmembrane helice. No signal peptide was detected (Figure 1-2).

The phylogenetic analysis revealed the similarity of M. edulis ABCG2 with other representative ABCG2 protein from different species (Figure 3). M. edulis amino acid sequence matched the most with Mytilus galloprovincialis (98\%), Crassostrea gigas (65\%) and Lottia gigantea ABCG2 (64\%) while identities with other vertebrates and invertebrates orthologs were comprised between $49 \%$ and $61 \%$ ( $49 \%$ with human protein).

\subsection{ABCG2 transcript levels in hemocytes and gills}

The expression of abcg2-like mRNAs was investigated in Mytilus edulis hemocytes and gills (

Figure 4). Transcript levels were normalized to efla. This housekeeping gene was stable amongst tissues (data not shown). Both tissues showed the presence of abcg2-like gene product. Furthermore, transcripts were significantly more abundant in gills $(2.5$ times, $p<0.01)$ than in hemocytes. 


\subsection{ABCG2 transporter activity}

BCRP efflux activity was investigated in hemocyte suspensions and gill tissues using bodipy prazosin (Cooray et al., 2004) and pheophorbide A (Robey et al., 2004) as ABCG2 pump allocrites. Cells were treated with pharmacological blockers characterized by their specificity for human $\mathrm{ABC}$ transporters (Table 1).

\subsubsection{In hemocytes}

BCRP efflux activity was explored in hemocyte subpopulations by flow cytometry. Cell fluorescence was analysed according criteria of cell size (EV expressed in $\mu \mathrm{m})$ and inner complexity (side-scatter signal). Two non-overlapping regions were defined on EV/SS dot plots. The region R1 corresponds to small semi-granular basophils and the region R2 to large granular and semi-granular cells called eosinophils (Figure 5a). The normalized intracellular fluorescence concentration (FL-FC, arbitrary units) was calculated from the ratio of FL to EV (Figure 5b).

The cell fluorescence varied according to the probe used. Bodipy prazosin was more accumulated in eosinophils. In contrary, pheophorbide A was slightly more concentrated in basophils. In the presence of $\mathrm{ABC}$ transporter inhibitors sildenafil, MK571, Ko134 and elacridar, bodipy prazosin accumulation increased significantly in hemocytes particularly in eosinophils ( $\mathrm{p}<0.01$ for MK571 and $\mathrm{p}<0.001$ for the other blockers), while pranlukast had no effect on dye efflux (Figure 5c). By contrast, pheophorbide A efflux was only non significantly inhibited by all blockers, at different levels.

To compare blockers effects on pump activity, the multidrug resistance activity factor was determined (Table 3). Cells charged with bodipy prazosin showed an increased MAF for most inhibitors (sildenafil, MK571, KPo134, elacridar) compared to hemocytes incubated with pheophorbide A. Furthermore, with bodipy prazosin no differences were noted between hemocyte subpopulations. By contrast, MAF values were less important in basophils loaded with pheophorbide A than in eosinophils.

\subsubsection{In gills}

ABCG2 pump activity was explored in gills with a microplate reader assay. Only MK571 and Ko134 significantly increased bodipy prazosin accumulation $(\mathrm{p}<0.05)$, indicating an inhibition of the dye efflux (Figure 6a). The other blockers induced a slight but non-significant increase in cell fluorescence. With the probe pheophorbide A, slight fluorescence increases were obtained mainly in gills pre-incubated with sildenafil or ko134, but no inhibitor produced result 
significantly different from control measurements. Furthermore, in control conditions, both BCRP allocrites were more effluxed from the anterior-labial part of gills (Figure 6b). In the presence of pump blockers (MK571 and Ko134), fluorescence increased and was more concentrated in the center and anterior side of the tissues.

Gills charged with bodipy prazosin showed higher MAF values compared to pheophorbide A. in the presence of Ko134, efflux activity was more important for both fluorescent probes (Table 4). However, MK571 showed a high MAF value only for bodipy prazosin.

\section{Discussion}

$\mathrm{ABC}$ transporters play an important role in cell detoxification. The first genome sequencing and analysis of Mytilus galloprovincialis recently pointed out Multidrug Associated Genes as significantly overrepresented in this genus (Murgarella et al., 2016). Until now, only B and C subfamilies were identified in the blue mussel. In this study, we expand the knowledge on $\mathrm{ABC}$ pump subtypes and investigate the presence of ABCG2 in Mytilus edulis tissues. To this purpose, we combined molecular and functional approaches to explore gene expression and pump activity in the gills and hemocytes.

\subsection{ABCG2 molecular characterization}

ABCG2 amino acid sequence was identified from the gills of Mytilus edulis and characterized. It contained typical conserved structural domains of $\mathrm{ABC}$ transporter. Characteristic motifs including the Walker A and B motifs are common to many ATP binding proteins while aromatic D, H and Q loops as well as ABC signature are unique to the family (Dean et al., 2001; Linton, 2007). They play an important role in the functioning of the transporter (Linton, 2007). According to the predicted structure, Mytilus edulis ABCG2 is a half transporter, with one NBD followed by one MSD and a molecular weight equal to $71.5 \mathrm{KDa}$ which is closely similar to human ABCG2 (Kathawala et al., 2015).

Phylogenetic analysis grouped the identified protein with other ABCG2 members from several species. Mytilus edulis ABCG2 was closely related to invertebrate transporters especially Mytilus galloprovincialis and Crassostrea gigas efflux pumps. This classification is not surprising considering that $\mathrm{ABC}$ transporters are well conserved across species. Most of the studies reported a strong homology between bivalve ABC pumps. For example, Huang et al. (2015) identified P-gp in the bivalve species $R$. philippinarum, $S$. subcrenata and T. granosa exhibiting high homology with other bivalve mollusks such as C. ariakensis, C. gigas, $M$. californianus and M. galloprovincialis. 
Since ABCG2 transcript has also been found in hemocytes, we quantified the abundance mRNAs in both tissues. ABCG2 copy number were 2 fold higher in gills than hemocytes. This apparent disparity in gene expression over tissues has been demonstrated for other members of ABC transporters. P-gp transcripts were more abundant in gills than hemocytes in the scallop C. farreri (Miao et al., 2014) and the mussel M. galloprovincialis (Della Torre et al., 2014; Franzellitti et al., 2016). Many authors suggested that the tissue-specific expression of ABC genes is a consequence of tissue involvement in adsorption, metabolism and elimination of toxic compounds (Della Torre et al., 2014; Huang et al., 2015). The latter hypothesis may be plausible nevertheless further investigations are needed to confirm it.

\subsection{ABCG2 pump efflux activity}

If ABCG2 expression has been poorly described in bivalves, data on pump activity are inexistent. Herein, we explored for the first time BCRP pump activity using fluorescent probes, allocrite to human BCRP, in combination with a battery of inhibitors. In hemocytes, analysis was performed considering two major subpopulations. The first is represented by small semi granular basophils while the second includes complex granulocytes and agranular hyalinocytes (Le Foll et al., 2010). Results showed that the rate of accumulated fluorescence varied according to both cell subtypes and allocrite probes. Either in basal condition or in the presence of blockers, bodipy prazosin was more concentrated in eosinophils and inversely pheophorbide A was more stored in basophils. In appearance, these probe heterogeneous distributions may be a consequence of pronounced activity localized in particular cell subpopulation as reported by other studies. In this respect, Rioult et al. (2014) demonstrated that ABCC activity was supported by Mytilus edulis granulocytes. However, herein even though probes are supposed to be both allocrite to ABCG2 (Robey et al., 2004; Shi et al., 2011), their distribution profiles in hemocytes were contradictory. These discrepancies can be accounted for by to a dual effect of transporter location and differential affinity of substrates to cell compartments. According to few studies, ABC pumps can be located in mammalian lysosomal membrane in addition of plasmalemma (Rajagopal and Simon, 2003; Wioland et al., 2000). Furthermore, in mussel blood cells, it has been shown a retention of the fluorescent P-gp substrate rhodamine B in lysosomes, reversible by verapamil as blocker (Svensson et al., 2003). Another explanation to the higher accumulation of bodipy prazosin in eosinophils would be the presence of an additional pump contributing to the observed activity. Actually, if pheophorbide A has been proved to be a single substrate to mammalian ABCG2 (Robey et al., 2004), the specificity of bodipy prazosin was more discussed. Several studies reported the efflux of bodipy prazosin by 
Human P-gp (Chufan et al., 2013; Kimchi-Sarfaty et al., 2002). In mussel hemocytes, the existence of an active P-gp is controversial. Classical ABCB blockers were ineffective on calcein-AM or rhodamine 123 efflux in hemocytes of M. edulis (Rioult et al., 2014) and $M$. galloprovincialis (Della Torre et al., 2014; Franzellitti et al., 2016). In contrast, rhodamine B efflux was inhibited by the same blockers in blood cells of the blue mussel (Svensson et al., 2003 ) and the freshwater painter's mussel (Zaja et al., 2006). According to these contradictory findings, the possibility of an ABCB pump interference in MXR activity cannot be excluded. It is probable that the mussel P-gp has an affinity profiles toward allocrites that differs from that of mammalian transporter and that the mussel efflux pump is capable to interact with other substrates like bodipy prazosin. Considering this latter point, a combination of allocrites and inhibitors is required to properly characterize the pump of interest.

In hemocytes, the specific blockers of mammalian BCRP, elacridar and Ko134, enhanced fluorescence level of both probes indicating an active role of ABCG2 in cell subpopulations. By contrast, sildenafil acted only on bodipy prazosin efflux and had no effect on pheophorbide A. This blocker has been described for reversing the resistance of ABCG2 and ABCB1 in Human cells (Shi et al., 2011). Surprisingly, classical inhibitors of C class transporter increased also the accumulation of fluorescent dyes. MK571 blocked the efflux of both probes while pranlukast had an effect only on pheophorbide A. Several studies used MK571 for his specific action against ABCC pump in bivalves like the blue mussel (Rioult et al., 2014), the Mediterranean mussel (Della Torre et al., 2014; Franzellitti et al., 2016), the Californian mussel (Luckenbach et al., 2008; Luckenbach and Epel, 2008) and the zebra mussel (Faria et al., 2016, 2011). However, in our study, it seems that this blocker is also able to interact with ABCG2 in mussels. Furthermore, Fischer et al. (2013) reported its action on zebrafish ABCB4. Thus, regarding this polyspecificity, results should be interpreted more carefully particularly when the tissue expresses multiple transporters.

In gills, dye accumulation was enhanced at different levels after treatment with blockers indicating a BCRP activity. Ko134 inhibited efficiently the efflux of bodipy prazosin $(\mathrm{MAF}=29 \pm 6.4)$ and pheophorbide $\mathrm{A}(\mathrm{MAF}=28 \pm 7.1)$, whereas, MK571 blocked more bodipy prazosin $(\mathrm{MAF}=38 \pm 8.1)$. The difference of substrate inhibition profiles compared to hemocytes may be due to the heterogeneous distribution of the transporter in gills. Indeed, BCRP efflux activity seems to be concentrated in the anterior side of gills suggesting a localized expression of ABCG2. ABC transporter localization has been explored in few studies. P-gp was detected in apical membranes of Mytilus galloprovincialis gills at the tissue environment interface and 
authors suggested his role as a barrier against entrance of xenobiotics (Luckenbach and Epel, 2008). Similarly, BCRP was found in apical border of mammalian tissues, (Leslie et al., 2005) and Saccostrea forskali gills (Kingtong et al., 2007) but its exact physiological implication remain unclear. Numerous studies confirmed its contribution to controlling the disposition and tissue exposure of endobiotics and xenobiotics including antibiotics, sterols, immunesuppressants, fluorescent dyes, photosensitizers (for review Horsey et al., 2016, Mo and Zhang 2012). Interestingly, ABCG2 seems also to play a role in immune modulation. Indeed, the transporter participate to the differentiation of skin Langerhans cells (Van de Ven et al., 2012) and myeloid dendritic cells (Jin and al., 2014). Consequently, we may think that Mytilus edulis ABCG2 has an immune defense function in hemocytes besides the detoxification task.

\section{Conclusion}

In this study, we identified and characterized a new $\mathrm{ABC}$ transporter belonging to $\mathrm{G} 2$ subtype in Mytilus edulis. Phylogenetic analysis revealed a sequence homology and a similar organizational structure than other ABCG2 family members. Furthermore, transcripts were expressed in hemocytes and with higher level in gills. Efflux activity assays show that Mytilus edulis has an active BCRP protein with an heterogeneous distribution in hemocyte subpopulations and gill tissues. Based on these results, it is clear that several ABC transporters contribute to MXR defense system in Mytilus edulis. Efforts have to be made to clarify the distinction between the different members and to explore their single function and specificity towards allocrites and chemosensitizers.

\section{Acknowledgements}

This work received fundings from the State/Region Plan Contract (CPER) allocated through the Research Federation FR CNRS 3730 SCALE (Sciences Appliquées à L'Environnement) and from the project IPOC supported by the Agence Nationale de la Recherche "Interactions between POllution and Climate changes: development of improved monitoring strategy" project (ANR-12-ISV7-0004). Yosra Ben Cheikh was a recipient for a Ph.D. grant from the Conseil Regional de Haute-Normandie. We thank SEBIO technical staff Aurélie Duflot for the contribution.

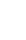




\section{References}

Akaishi, F.M., St-Jean, S.D., Bishay, F., Clarke, J., da S Rabitto, I., de Oliveira Ribeiro, C.A., 2007. Immunological responses, histopathological finding and disease resistance of blue mussel (Mytilus edulis) exposed to treated and untreated municipal wastewater. Aquat. Toxicol. Amst. Neth. 82, 1-14. doi:10.1016/j.aquatox.2007.01.008

Anita H Poulsen, E.B.I., 2012. Chemically induced immunosuppression and disease susceptibility in marine wildlife: a literature review.

Auffret, M., Rousseau, S., Boutet, I., Tanguy, A., Baron, J., Moraga, D., Duchemin, M., 2006. A multiparametric approach for monitoring immunotoxic responses in mussels from contaminated sites in Western Mediterranea. Ecotoxicol. Environ. Saf. 63, 393-405. doi:10.1016/j.ecoenv.2005.10.016

Bard, S.M., 2000. Multixenobiotic resistance as a cellular defense mechanism in aquatic organisms. Aquat. Toxicol. 48, 357-389. doi:10.1016/S0166-445X(00)00088-6

Chen, H., Zha, J., Yuan, L., Wang, Z., 2015. Effects of fluoxetine on behavior, antioxidant enzyme systems, and multixenobiotic resistance in the Asian clam Corbicula fluminea. Chemosphere 119, 856-862. doi:10.1016/j.chemosphere.2014.08.062

Chufan, E.E., Kapoor, K., Sim, H.-M., Singh, S., Talele, T.T., Durell, S.R., Ambudkar, S.V., 2013. Multiple Transport-Active Binding Sites Are Available for a Single Substrate on Human P-Glycoprotein (ABCB1). PLOS ONE 8, e82463. doi:10.1371/journal.pone.0082463

Cooray, H.C., Janvilisri, T., van Veen, H.W., Hladky, S.B., Barrand, M.A., 2004. Interaction of the breast cancer resistance protein with plant polyphenols. Biochem. Biophys. Res. Commun. 317, 269-275. doi:10.1016/j.bbrc.2004.03.040

Dean, M., Rzhetsky, A., Allikmets, R., 2001. The human ATP-binding cassette (ABC) transporter superfamily. Genome Res. 11, 1156-1166. doi:10.1101/gr.184901

Della Torre, C., Bocci, E., Focardi, S.E., Corsi, I., 2014. Differential ABCB and ABCC gene expression and efflux activities in gills and hemocytes of Mytilus galloprovincialis and their involvement in cadmium response. Mar. Environ. Res. 93, 56-63. doi:10.1016/j.marenvres.2013.06.005

Epel, D., Luckenbach, T., Stevenson, C.N., Macmanus-Spencer, L.A., Hamdoun, A., Smital, T., 2008. EFFLUX TRANSPORTERS: Newly Appreciated Roles in Protection against Pollutants. Environ. Sci. Technol. 42, 3914-3920.

Faria, M., Navarro, A., Luckenbach, T., Piña, B., Barata, C., 2011. Characterization of the multixenobiotic resistance (MXR) mechanism in embryos and larvae of the zebra mussel (Dreissena polymorpha) and studies on its role in tolerance to single and mixture combinations of toxicants. Aquat. Toxicol. Amst. Neth. 101, 78-87. doi:10.1016/j.aquatox.2010.09.004

Faria, M., Pavlichenko, V., Burkhardt-Medicke, K., Soares, A.M.V.M., Altenburger, R., Barata, C., Luckenbach, T., 2016. Use of a combined effect model approach for discriminating between $\mathrm{ABCB} 1$ - and $\mathrm{ABCC} 1$-type efflux activities in native bivalve gill tissue. Toxicol. Appl. Pharmacol. 297, 56-67. doi:10.1016/j.taap.2016.02.020

Farris, J.L., Hassel, J.H.V., 2006. Freshwater Bivalve Ecotoxicology. CRC Press.

Fischer, S., Klüver, N., Burkhardt-Medicke, K., Pietsch, M., Schmidt, A.-M., Wellner, P., Schirmer, K., Luckenbach, T., 2013. Abcb4 acts as multixenobiotic transporter and active barrier against chemical uptake in zebrafish (Danio rerio) embryos. BMC Biol. 11, 69. doi:10.1186/1741-7007-11-69

Franzellitti, S., Striano, T., Valbonesi, P., Fabbri, E., 2016. Insights into the regulation of the MXR response in haemocytes of the Mediterranean mussel (Mytilus galloprovincialis). Fish Shellfish Immunol. 58, 349-358. doi:10.1016/j.fsi.2016.09.048 
Giarratano, E., Duarte, C.A., Amin, O.A., 2010. Biomarkers and heavy metal bioaccumulation in mussels transplanted to coastal waters of the Beagle Channel. Ecotoxicol. Environ. Saf. 73, 270-279. doi:10.1016/j.ecoenv.2009.10.009

Gottesman, M.M., Ling, V., 2006. The molecular basis of multidrug resistance in cancer: the early years of P-glycoprotein research. FEBS Lett. 580, 998-1009. doi:10.1016/j.febslet.2005.12.060

Gupta, S.K., Singh, J., 2011. Evaluation of mollusc as sensitive indicatior of heavy metal pollution in aquatic system: A review. IIOAB J. 2, 49-57.

Haberkorn, H., Tran, D., Massabuau, J.-C., Ciret, P., Savar, V., Soudant, P., 2011. Relationship between valve activity, microalgae concentration in the water and toxin accumulation in the digestive gland of the Pacific oyster Crassostrea gigas exposed to Alexandrium minutum. Mar. Pollut. Bull. 62, 1191-1197. doi:10.1016/j.marpolbul.2011.03.034

Hégaret, H., Wikfors, G.H., Shumway, S.E., 2007. Diverse feeding responses of five species of bivalve mollusc when exposed to three species of harmful algae. J. Shellfish Res. 26, 549-559. doi:10.2983/0730-8000(2007)26[549:DFROFS]2.0.CO;2

Horsey, A.J., Cox, M.H., Sarwat, S., Kerr, I.D., 2016. The multidrug transporter ABCG2: still more questions than answers. Biochem. Soc. Trans. 44, 824-830. doi:10.1042/BST20160014

Huang, L., Liu, S.-L., Zheng, J.-W., Li, H.-Y., Liu, J.-S., Yang, W.-D., 2015. P-glycoprotein and its inducible expression in three bivalve species after exposure to Prorocentrum lima. Aquat. Toxicol. Amst. Neth. 169, 123-132. doi:10.1016/j.aquatox.2015.10.012

Huang, L., Wang, J., Chen, W.-C., Li, H.-Y., Liu, J.-S., Jiang, T., Yang, W.-D., 2014. Pglycoprotein expression in Perna viridis after exposure to Prorocentrum lima, a dinoflagellate producing DSP toxins. Fish Shellfish Immunol. 39, 254-262. doi:10.1016/j.fsi.2014.04.020

Jin, J.-O., Zhang, W., Wong, K.-W., Kwak, M., van Driel, I.R., Yu, Q., 2014. Inhibition of Breast Cancer Resistance Protein (ABCG2) in Human Myeloid Dendritic Cells Induces Potent Tolerogenic Functions during LPS Stimulation. PLoS ONE 9. doi:10.1371/journal.pone.0104753

Kathawala, R.J., Gupta, P., Ashby, C.R., Chen, Z.-S., 2015. The modulation of ABC transporter-mediated multidrug resistance in cancer: a review of the past decade. Drug Resist. Updat. Rev. Comment. Antimicrob. Anticancer Chemother. 18, 1-17. doi:10.1016/j.drup.2014.11.002

Kimchi-Sarfaty, C., Gribar, J.J., Gottesman, M.M., 2002. Functional Characterization of Coding Polymorphisms in the HumanMDR1 Gene Using a Vaccinia Virus Expression System. Mol. Pharmacol. 62, 1-6. doi:10.1124/mol.62.1.1

Kingtong, S., Chitramvong, Y., Janvilisri, T., 2007. ATP-binding cassette multidrug transporters in Indian-rock oyster Saccostrea forskali and their role in the export of an environmental organic pollutant tributyltin. Aquat. Toxicol. 85, 124-132. doi:10.1016/j.aquatox.2007.08.006

Köhler, A., Lauritzen, B., Jansen, D., Böttcher, P., Teguliwa, L., Krüner, G., Broeg, K., 1998. Detection of P-glycoprotein mediated MDR/MXR in Caranus maenas hepatopancreas by immuno-gold-silver labeling. Mar. Environ. Res., Pollutant Responses in Marine Organisms 46, 411-414. doi:10.1016/S0141-1136(97)00069-X

Kurelec, B., 1992. The multixenobiotic resistance mechanism in aquatic organisms. Crit. Rev. Toxicol. 22, 23-43. doi:10.3109/10408449209145320

Kurelec, B., Krca, S., Pivcevic, B., Ugarković, D., Bachmann, M., Imsiecke, G., Müller, W.E., 1992. Expression of P-glycoprotein gene in marine sponges. Identification and characterization of the $125 \mathrm{kDa}$ drug-binding glycoprotein. Carcinogenesis 13, 69-76. 
Kurelec, B., Pivcević, B., 1989. Distinct glutathione-dependent enzyme activities and a verapamil-sensitive binding of xenobiotics in a fresh-water mussel Anodonta cygnea. Biochem. Biophys. Res. Commun. 164, 934-940.

Lacroix, C., Coquillé, V., Guyomarch, J., Auffret, M., Moraga, D., 2014. A selection of reference genes and early-warning mRNA biomarkers for environmental monitoring using Mytilus spp. as sentinel species. Mar. Pollut. Bull. 86, 304-313.

Le Foll, F., Rioult, D., Boussa, S., Pasquier, J., Dagher, Z., Leboulenger, F., 2010. Characterisation of Mytilus edulis hemocyte subpopulations by single cell time-lapse motility imaging. Fish Shellfish Immunol. 28, 372-386. doi:10.1016/j.fsi.2009.11.011

Lebedeva, I.V., Pande, P., Patton, W.F., 2011. Sensitive and Specific Fluorescent Probes for Functional Analysis of the Three Major Types of Mammalian ABC Transporters. PLoS ONE 6, e22429. doi:10.1371/journal.pone.0022429

Lepist, E.-I., Phan, T.K., Roy, A., Tong, L., Maclennan, K., Murray, B., Ray, A.S., 2012. Cobicistat boosts the intestinal absorption of transport substrates, including HIV protease inhibitors and GS-7340, in vitro. Antimicrob. Agents Chemother. 56, 54095413. doi:10.1128/AAC.01089-12

Leslie, E.M., Deeley, R.G., Cole, S.P.C., 2005. Multidrug resistance proteins: role of Pglycoprotein, MRP1, MRP2, and BCRP (ABCG2) in tissue defense. Toxicol. Appl. Pharmacol. 204, 216-237. doi:10.1016/j.taap.2004.10.012

Linton, K.J., 2007. Structure and Function of ABC Transporters. Physiology 22, 122-130. doi:10.1152/physiol.00046.2006

Luckenbach, T., Altenburger, R., Epel, D., 2008. Teasing apart activities of different types of ABC efflux pumps in bivalve gills using the concepts of independent action and concentration addition. Mar. Environ. Res. 66, 75-76. doi:10.1016/j.marenvres.2008.02.027

Luckenbach, T., Epel, D., 2008. ABCB- and ABCC-type transporters confer multixenobiotic resistance and form an environment-tissue barrier in bivalve gills. Am. J. Physiol. Regul. Integr. Comp. Physiol. 294, R1919-1929. doi:10.1152/ajpregu.00563.2007

Luedeking, A., Koehler, A., 2002. Identification of six mRNA sequences of genes to multixenobiotic resistance (MXR) and biotransformation in Mytilus edulis. Mar. Ecol.-Prog. Ser. - MAR ECOL-PROGR SER 238, 115-124. doi:10.3354/meps238115

Luedeking, A., Van Noorden Cornelis J. F., Koehler A., 2005. Identification and characterisation of a multidrug resistance-related protein mRNA in the blue mussel Mytilus edulis. MEPS 286,167-175. doi:10.3354/meps286167.

McFadzen, I., Eufemia, N., Heath, C., Epel, D., Moore, M., Lowe, D., 2000. Multidrug resistance in the embryos and larvae of the mussel Mytilus edulis. Mar. Environ. Res. 50, 319-323.

Miao, J., Cai, Y., Pan, L., Li, Z., 2014. Molecular cloning and characterization of a MXRrelated P-glycoprotein cDNA in scallop Chlamys farreri: transcriptional response to benzo(a)pyrene, tetrabromobisphenol A and endosulfan. Ecotoxicol. Environ. Saf. 110, 136-142. doi:10.1016/j.ecoenv.2014.08.029

Minier, C., Forget-Leray, J., Bjørnstad, A., Camus, L., 2008. Multixenobiotic resistance, acetyl-choline esterase activity and total oxyradical scavenging capacity of the Arctic spider crab, Hyasaraneus, following exposure to bisphenol A, tetra bromo diphenyl ether and diallyl phthalate. Mar. Pollut. Bull. 56, 1410-1415. doi:10.1016/j.marpolbul.2008.05.005

Mo, W., Zhang, J.-T., 2011. Human ABCG2: structure, function, and its role in multidrug resistance. Int. J. Biochem. Mol. Biol. 3, 1-27. 
Murgarella, M., Puiu, D., Novoa, B., Figueras, A., Posada, D., Canchaya, C., 2016. A First Insight into the Genome of the Filter-Feeder Mussel Mytilus galloprovincialis. PLOS ONE 11, e0151561. doi:10.1371/journal.pone.0151561

Nagayama, S., Chen, Z.S., Kitazono, M., Takebayashi, Y., Niwa, K., Yamada, K., Tani, A., Haraguchi, M., Sumizawa, T., Furukawa, T., Aikou, T., Akiyama, S., 1998. Increased sensitivity to vincristine of MDR cells by the leukotriene D4 receptor antagonist, ONO-1078. Cancer Lett. 130, 175-182.

Navarro, A., Weißbach, S., Faria, M., Barata, C., Piña, B., Luckenbach, T., 2012. Abcb and Abcc transporter homologs are expressed and active in larvae and adults of zebra mussel and induced by chemical stress. Aquat. Toxicol. Amst. Neth. 122-123, 144152. doi:10.1016/j.aquatox.2012.06.008

Nielsen, D., Skovsgaard, T., 1992. P-glycoprotein as multidrug transporter: a critical review of current multidrug resistant cell lines. Biochim. Biophys. Acta 1139, 169-183.

Olson, D.P., Taylor, B.J., Ivy, S.P., 2001. Detection of MRP functional activity: calcein AM but not BCECF AM as a Multidrug Resistance-related Protein (MRP1) substrate. Cytometry 46, 105-113.

Rajagopal, A., Simon, S.M., 2003. Subcellular Localization and Activity of Multidrug Resistance Proteins. Mol. Biol. Cell 14, 3389-3399. doi:10.1091/mbc.E02-11-0704

Rioult, D., Pasquier, J., Boulangé-Lecomte, C., Poret, A., Abbas, I., Marin, M., Minier, C., Le Foll, F., 2014. The multi-xenobiotic resistance (MXR) efflux activity in hemocytes of Mytilus edulis is mediated by an ATP binding cassette transporter of class C (ABCC) principally inducible in eosinophilic granulocytes. Aquat. Toxicol. Amst. Neth. 153, 98-109. doi:10.1016/j.aquatox.2013.11.012

Robey, R.W., Steadman, K., Polgar, O., Morisaki, K., Blayney, M., Mistry, P., Bates, S.E., 2004. Pheophorbide a is a specific probe for ABCG2 function and inhibition. Cancer Res. 64, 1242-1246.

Sarkadi, B., Homolya, L., Szakács, G., Váradi, A., 2006. Human multidrug resistance ABCB and $\mathrm{ABCG}$ transporters: participation in a chemoimmunity defense system. Physiol. Rev. 86, 1179-1236. doi:10.1152/physrev.00037.2005

Sato, H., Siddig, S., Uzu, M., Suzuki, S., Nomura, Y., Kashiba, T., Gushimiyagi, K., Sekine, Y., Uehara, T., Arano, Y., Yamaura, K., Ueno, K., 2015. Elacridar enhances the cytotoxic effects of sunitinib and prevents multidrug resistance in renal carcinoma cells. Eur. J. Pharmacol. 746, 258-266. doi:10.1016/j.ejphar.2014.11.021

Sharom, F.J., 2008. ABC multidrug transporters: structure, function and role in chemoresistance. Pharmacogenomics 9, 105-127. doi:10.2217/14622416.9.1.105

Shi, Z., Tiwari, A.K., Shukla, S., Robey, R.W., Singh, S., Kim, I.-W., Bates, S.E., Peng, X., Abraham, I., Ambudkar, S.V., Talele, T.T., Fu, L.-W., Chen, Z.-S., 2011. Sildenafil reverses $\mathrm{ABCB} 1$ - and $\mathrm{ABCG} 2-$-mediated chemotherapeutic drug resistance. Cancer Res. 71, 3029-3041. doi:10.1158/0008-5472.CAN-10-3820

Svensson, S., Särngren, A., Förlin, L., 2003. Mussel blood cells, resistant to the cytotoxic effects of okadaic acid, do not express cell membrane p-glycoprotein activity (multixenobiotic resistance). Aquat. Toxicol. Amst. Neth. 65, 27-37.

Toomey, B.H., Epel, D., 1993. Multixenobiotic Resistance in Urechis caupo Embryos: Protection From Environmental Toxins. Biol. Bull. 185, 355-364.

Van de Ven, R., Lindenberg, J.J., Reurs, A.W., Scheper, R.J., Scheffer, G.L., de Gruijl, T.D., 2012. Preferential Langerhans cell differentiation from CD34(+) precursors upon introduction of ABCG2 (BCRP). Immunol. Cell Biol. 90, 206-215. doi:10.1038/icb.2011.25

Wioland, M.A., Fleury-Feith, J., Corlieu, P., Commo, F., Monceaux, G., Lacau-St-Guily, J., Bernaudin, J.F., 2000. CFTR, MDR1, and MRP1 immunolocalization in normal 
614

615

616

617

618

619 620 621 622

623

624 625

626 624

human nasal respiratory mucosa. J. Histochem. Cytochem. Off. J. Histochem. Soc. 48, $1215-1222$.

Xuereb, B., Forget-Leray, J., Souissi, S., Glippa, O., Devreker, D., Lesueur, T., Marie, S., Danger, J.-M., Boulangé-Lecomte, C., 2012. Molecular characterization and mRNA expression of grp78 and hsp90A in the estuarine copepod Eurytemora affinis. Cell Stress Chaperones. doi:10.1007/s12192-012-0323-9

Zaja, R., Klobucar, G.I.V., Sauerborn Klobucar, R., Hackenberger, B.K., Smital, T., 2006. Haemolymph as compartment for efficient and non-destructive determination of Pglycoprotein (Pgp) mediated MXR activity in bivalves. Comp. Biochem. Physiol. Toxicol. Pharmacol. CBP 143, 103-112. doi:10.1016/j.cbpc.2005.12.009

(1)

16

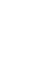




\section{Figure legend}

Figure 1. Topology of the Mytilus edulis ABCG2 protein with membrane spanning domains (MSD) as predicted by TMHMM v2.0 and nucleotide binding domain (NBD) indicated by the Walkers A and B, the C motif, the Q-, D- and H-loops. GS marks the N-glycosylation sites.

Figure 2. ClustalW alignments of Mytilus edulis ABCG2 with human ABCG2 transporter (GenBank accession no. Q9UNQ0). Conserved Walker A and B motifs, the ABC signature C motif, Q-, D- and H-loops are indicated with coloured boxes. Underlined sections represent transmembrane helices according to the TMHMM program. GS marks the N-glycosylation sites. $*$ indicate similar amino acid

Figure 3. Phylogenetic tree based on multiple alignment (ClustalX) of various ABCG2 transporter subtype sequences from diverse vertebrates and invertebrates. Tree was generated using the neighbour-joining method, distances are shown at the nodes.

Figure 4. Relative expression of abcg2-like in Mytilus edulis hemocytes and gills. Transcript levels are normalized to efl $\alpha$ (hk gene). Letters indicate significant differences (mean \pm SEM, $n=5, p<0.01$, Student's t-test).

Figure 5. Flow cytometry analysis of BCRP efflux activity in hemocyte subpopulations. Cells were preincubated for $30 \mathrm{~min}$ with various blockers at $30 \mu \mathrm{M}$ and then a fluorescent dye, bodipy prazosin $(0.5 \mu \mathrm{M})$ or pheophorbide A $(5 \mu \mathrm{M})$, was loaded for $15 \mathrm{~min}$. $\boldsymbol{a}$, dot plot of cell Coulter-type electronic volume (EV), graphed versus cell complexity side-scatter (SS). Two subpopulations of interest have been delimited by off-line analysis and considered to correspond to basophils and eosinophils. $\boldsymbol{b}$, normalized fluorescence (FL1-FC, for FL1fluorescence concentration) distributions of the sample presented in $a$, expressed as the ratio of FL1 to cell size. $\boldsymbol{c}$, mean fluorescence of hemocytes in absence or presence of blockers, for respective fluorescent dyes (bars are SEM, $n=3-5$ ). * indicates significant differences from the control (Student's t-test, $\left.{ }^{*} \mathrm{p}<0.05\right)$ and $\S$ marks differences between hemocyte subpopulations (Student's t-test, $\S \mathrm{p}<0.05$ )

Figure 6. BCRP efflux activity in gills measured by dye accumulation in presence of $A B C$ transporter inhibitors. Cells were preincubated for $30 \mathrm{~min}$ with various blockers at $30 \mu \mathrm{M}$ and then a fluorescent dye, bodipy prazosin $(0.5 \mu \mathrm{M})$ or pheophorbide $\mathrm{A}(5 \mu \mathrm{M})$, was loaded for 15 min. $\boldsymbol{a}$, mean of fluorescence of gills in absence or presence of blockers and, for respective fluorescent dyes (bars are SEM, $\mathrm{n}=4,{ }^{*} \mathrm{p}<0.05$ Student's t-test). $b$, colour-coded cartography of 
658 probes accumulation in gills in control and blocked samples (P: posterior, A:anterior, DS:

659 Dorsal side, VS: Ventral side)

660

661

662

663

664

665

666

667

668

669

670

671

672

673

674

675

676

677

678

679

680

681

682

683

684

685

686

687

688 
Table 1. Specificity of ABC blockers used in this study

\begin{tabular}{|l|l|l|}
\hline Chemicals & Blocker specificity & Reference \\
\hline Sildenafil & ABCB/ABCG2 & Shi et al., 2011 \\
\hline MK571 & ABCC & Olson et al., 2001 \\
\hline Pranlukast (ONO-1078) & ABCC & Nagayama et al., 1998 \\
\hline Ko134 & ABCG2 & Lepist et al., 2012 \\
\hline Elacridar & ABCG2 & Sato et al., 2015 \\
\hline
\end{tabular}

691

692 Table 2. Primers used in this study

\begin{tabular}{|c|c|c|c|c|c|c|}
\hline Gene & $\begin{array}{l}\text { Accession } \\
\text { number }\end{array}$ & Fw 5'-3' & Rev 5'-3' & $\begin{array}{l}\text { Tm } \\
\left({ }^{\circ} \mathrm{C}\right)\end{array}$ & $\begin{array}{c}\text { Amplicon } \\
\text { size (pb) }\end{array}$ & Reaction \\
\hline \multirow{4}{*}{ abcg 2} & gi|4067177477 & CCCTGCTGGTTTAAGTGGAC & ATCAACACCAACCACTGCAT & 59 & 879 & PCR \\
\hline & KX551963 & GCGAGATGGACAAACGAACC & ATGGATTTGGTCCTTGCACT & 60 & 2248 & PCR \\
\hline & KX551963 & TGGTGGGCTATGTTGTTCAGGATGA & CTTTCTCCACCAGATACACCACGGA & 64 & 214 & RACE PCR \\
\hline & KX551963 & TGTGCTATTTTTAGATGAACCAACA & TCСТTCСТTTTAATGCTAATCTTCTC & 59 & 95 & qPCR \\
\hline efla & AF063420.1 & TGTGCTATTTTTAGATGAACCAACA & ТССТТССТTТTAАТGСТААТСТTСТС & 59 & 61 & qPCR \\
\hline
\end{tabular}

693

694 Table 3.Comparison of BCRP activity detection in hemocyte subpopulations using BCRP 695 probes and inhibitors of different specificity

\begin{tabular}{|c|c|c|c|c|c|c|}
\hline BCRP Probe & $\begin{array}{c}\text { Hemocyte } \\
\text { subpopulation }\end{array}$ & Sildenafil & MK571 & Ko134 & Elacridar & Pranlukast \\
\hline \multirow{2}{*}{ Bodipy prazosin } & Basophils & $55 \pm 6.9$ & $38 \pm 11.7$ & $25 \pm 9.9$ & $44 \pm 5.3$ & 0 \\
\cline { 2 - 7 } & Eosinophils & $53 \pm 2.5$ & $39 \pm 5.6$ & $32 \pm 1.3$ & $46 \pm 2.5$ & 0 \\
\hline \multirow{2}{*}{ Pheophorbide A } & Basophils & $9 \pm 8.6$ & $35 \pm 11.9$ & $35 \pm 15.8$ & $21 \pm 13.6$ & $36 \pm 12.1$ \\
\cline { 2 - 7 } & Eosinophils & $18 \pm 12.3$ & $50 \pm 8.3$ & $41 \pm 14.7$ & $25 \pm 12.5$ & $41 \pm 12.6$ \\
\hline
\end{tabular}

696 Average MAF values \pm SEM for three (for pheophorbide A) and five (for bodipy prazosin) representative experiments are 697 provided. Negative MAF values have been replaced with 0.

698 Table 4. Comparison of BCRP activity detection gills using BCRP probes and inhibitors of 699 different specificity

\begin{tabular}{|l|l|l|l|l|l|}
\hline BCRP Probe & Sildenafil & MK571 & Ko134 & Elacridar & Pranlukast \\
\hline Bodipy prazosin & $12 \pm 8.3$ & $38 \pm 8.1$ & $29 \pm 6.4$ & $18 \pm 7.2$ & $17 \pm 10.5$ \\
\hline Pheophorbide A & $22 \pm 4.2$ & $13 \pm 8$ & $28 \pm 7.1$ & $17 \pm 4.9$ & $6 \pm 15.2$ \\
\hline
\end{tabular}




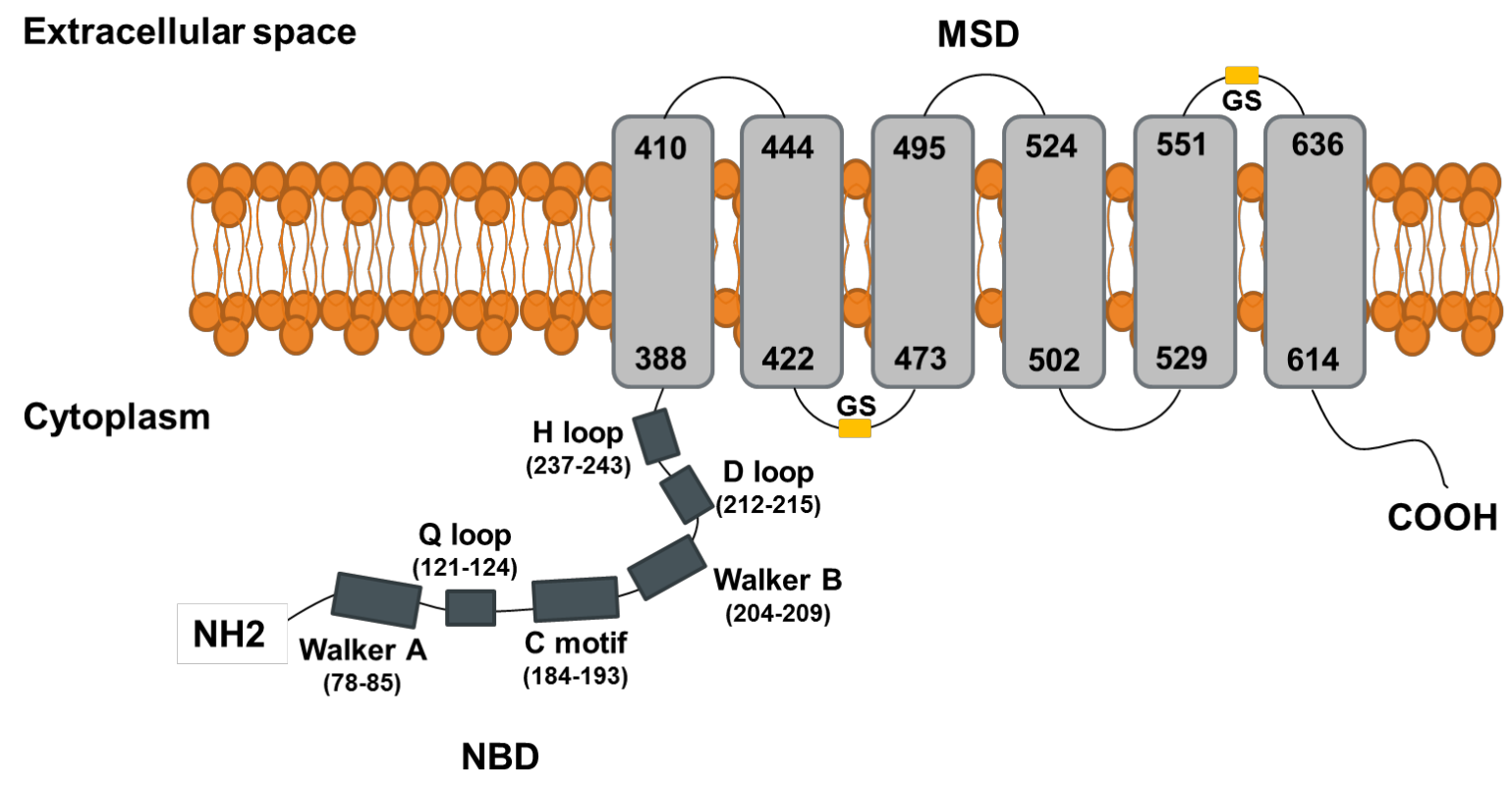


Mussel ABCG2 Human ABCG2

Mussel ABCG2 Human ABCG2

Mussel ABCG2 Human ABCG2

Mussel ABCG2 Human ABCG2

Mussel ABCG2 Human ABCG2

Mussel ABCG2 Human ABCG2

Mussel ABCG2 Human ABCG2

Mussel ABCG2 Human ABCG2

Mussel ABCG2 Human ABCG2

Mussel ABCG2 Human ABCG2

Mussel ABCG2 Human ABCG2
MSKTN-GVPNPAYNYGSKDEHSKVDMESSHYERAATITGHNIVYTVDVKT--KPCCGQIE 57 **SS*VE*FI*VSQGNTNGFPATASNDLKAFTEG*VLSF***C*R*KL*SGFL**RKPV* 60 Walker A

KKEILKGINGIFKPGMNAILGPTGSGKSSVLDILAGRKDPAGLSGHLLLDGSPPPENFKC 117

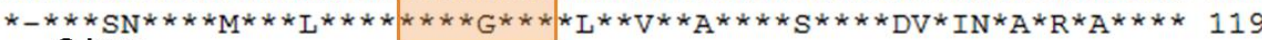
Q-loop

MVGYVVQDDVVMGGLTVRENFEFSATLRLPSDVTKADRKDRVDNVINELGLNKCADTKVG 177 NS $* * * * * * * * * * * T * * * * * * \mathrm{~L}^{*} * * \mathrm{~A} * * * \mathrm{ATTM} * \mathrm{NHEKNE}{ }^{*} \mathrm{INR}^{* *} \mathrm{Q} * * * * \mathrm{D} * \mathrm{~V} * * \mathrm{~S} * * * 179$ C motif Walker B D-loop

NEFFRGVSGGERKRTNIGMELIISPPVLFLDE PT PGLDANTANSVMMLLRRLALKGRTVV 237 $\mathrm{TQ}^{*} \mathrm{I} * * * * * * * * * * * \mathrm{~S} * * * * * * \mathrm{TD} * \mathrm{~S}\left[* * * * * * * * * * * \mathrm{SS} * * * \mathrm{~A} * \mathrm{LI} * * \mathrm{~K} * \mathrm{MSKQ} \mathrm{Q}^{* * *} \mathrm{II} 239\right.$ H-loop

FSIHQPRYSIFKLFDSLMLLSMGECVYHGPASESLEYFKSIGYVIEEHNNPPDFFLDVIN 297 $* * * * * * * * * * * * * * * * * \mathrm{~T} * * \mathrm{AS}{ }^{*} \mathrm{RLMF} * * * * \mathrm{Q}^{*} \mathrm{~A} \mathrm{G}^{*} \mathrm{C}^{*} \mathrm{E}^{*} \mathrm{~A} * * \mathrm{HC}^{*} \mathrm{AY} * * * \mathrm{~A} * * * * * I * * 299$

GEAN----HSEKDINEISVKDIEEVHTKLVSSFQKSTLNSRLQNQMNPILQQYQHAVETN 353 *DSTAVALNR *E* FKATEIIEPSKQDKP*IEKLAEIYV**SFYKETKAE*H*ISGGEKKK 359

TVKVLPKIEYATSAFTQFRAVSGRTILNLLRNPQLSVMQWLVLI IFGLIVGAIYWQLEKD 413

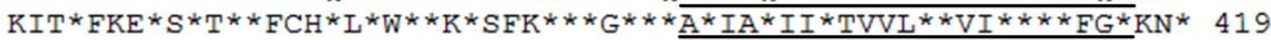
GS CVTGIQNRVGAFFF I IMNQVFGNLSAVELF IKERS I FMHENVSGFYRVSAYFFSK I ICDV 473

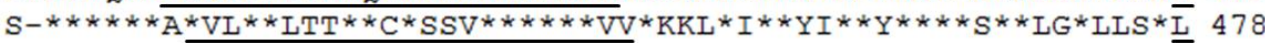

IPMRLI PVILFSAVTYFMLGLRLAAENFFLYVLSLFLVAMSASGIAFFFSATVSIFAVAN 533

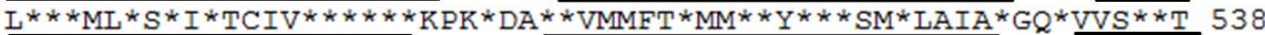
GS

LCIALTYVFMMVFSGLLVNVSSVPSWLRWLKWASLFRYGLNALDINELKDMTFSN----- 588

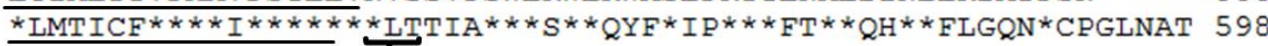
GS

GTATC---SATGNDYLIDQNI PYQTSWDFWQNIVALGAMSVISMTGTYIQLRRMKK-- 641

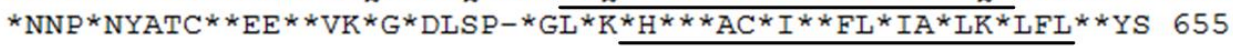




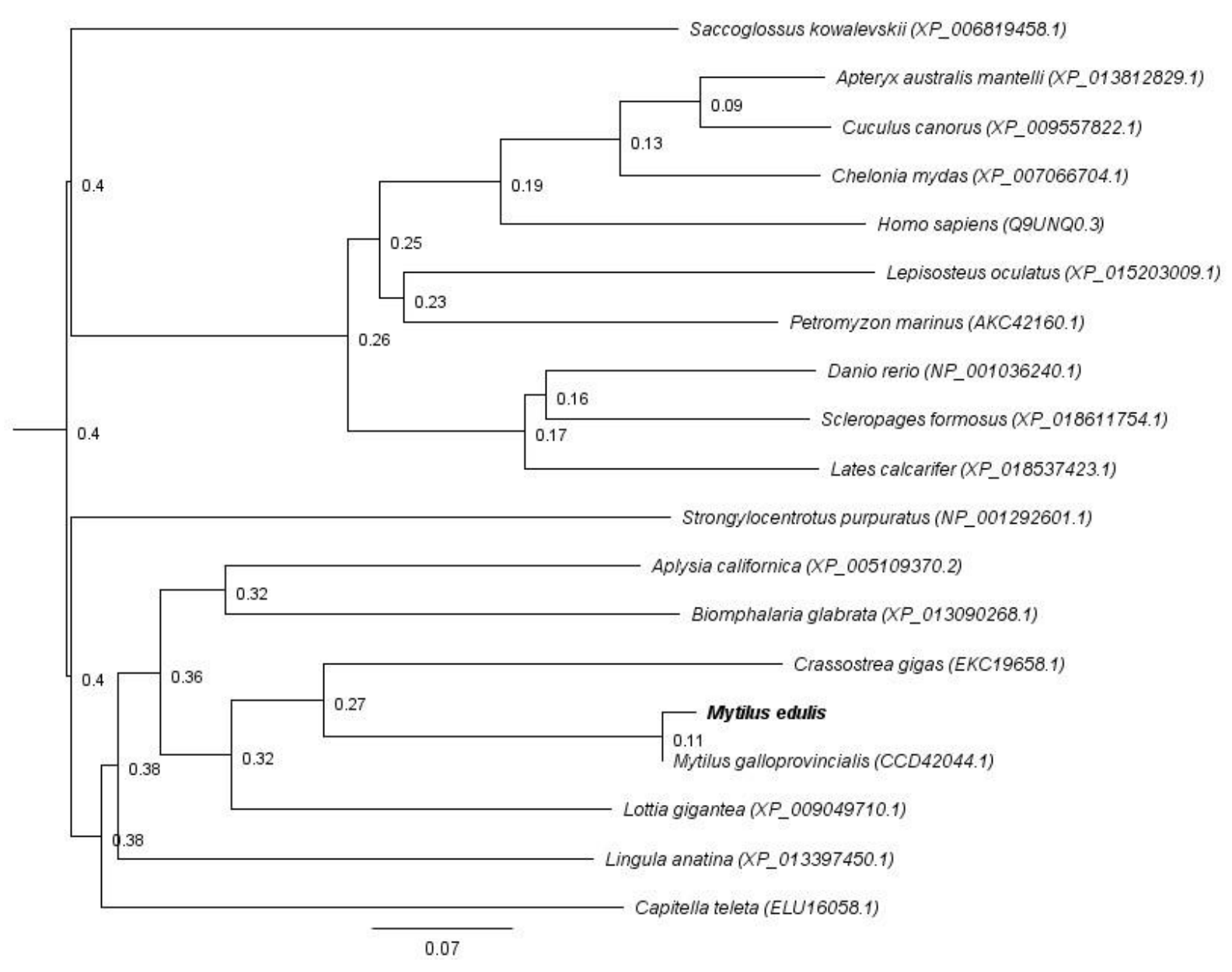




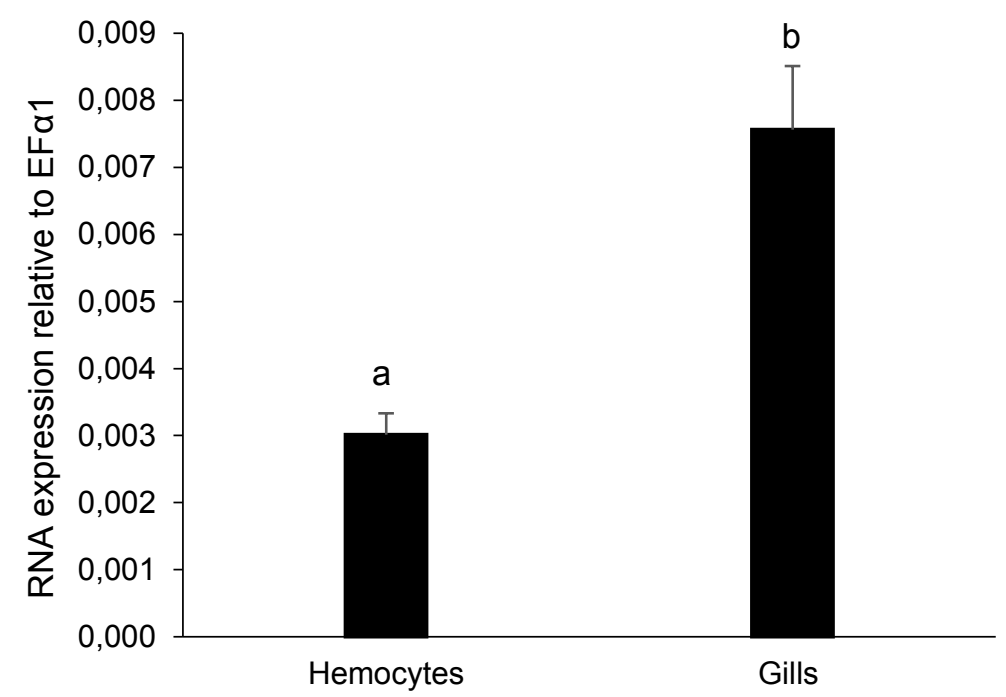


(a)

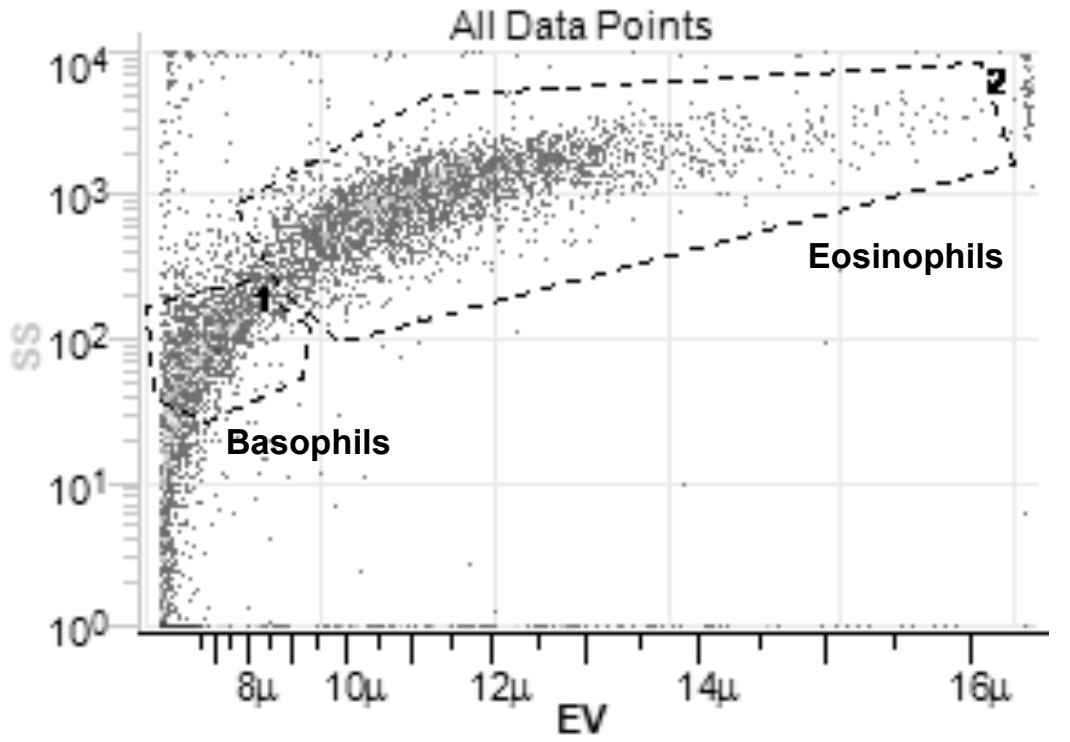

\section{Bodipy prazosin}

(c)

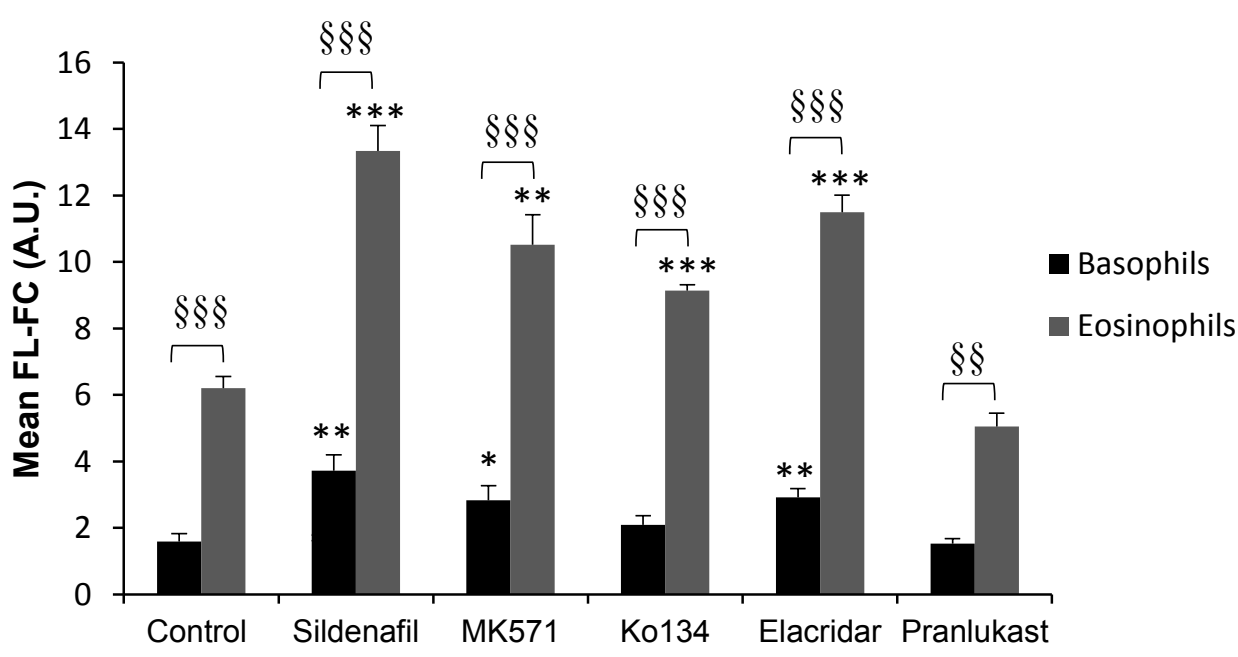

(b)

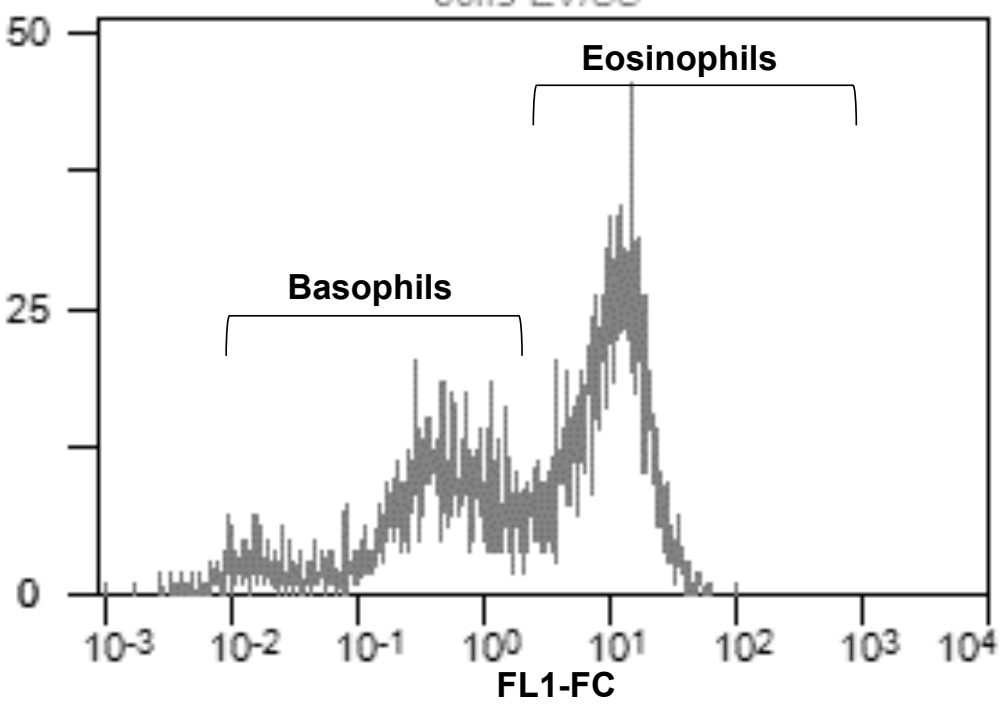

Pheophorbide A

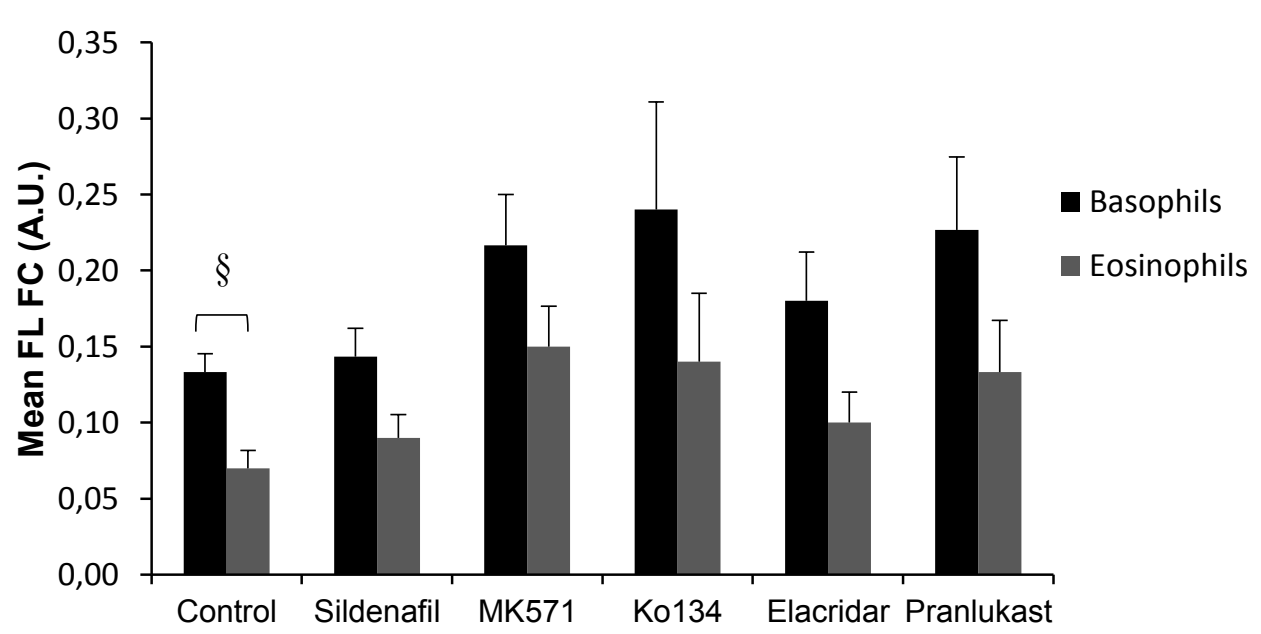




\section{Bodipy prazosin}

(a)

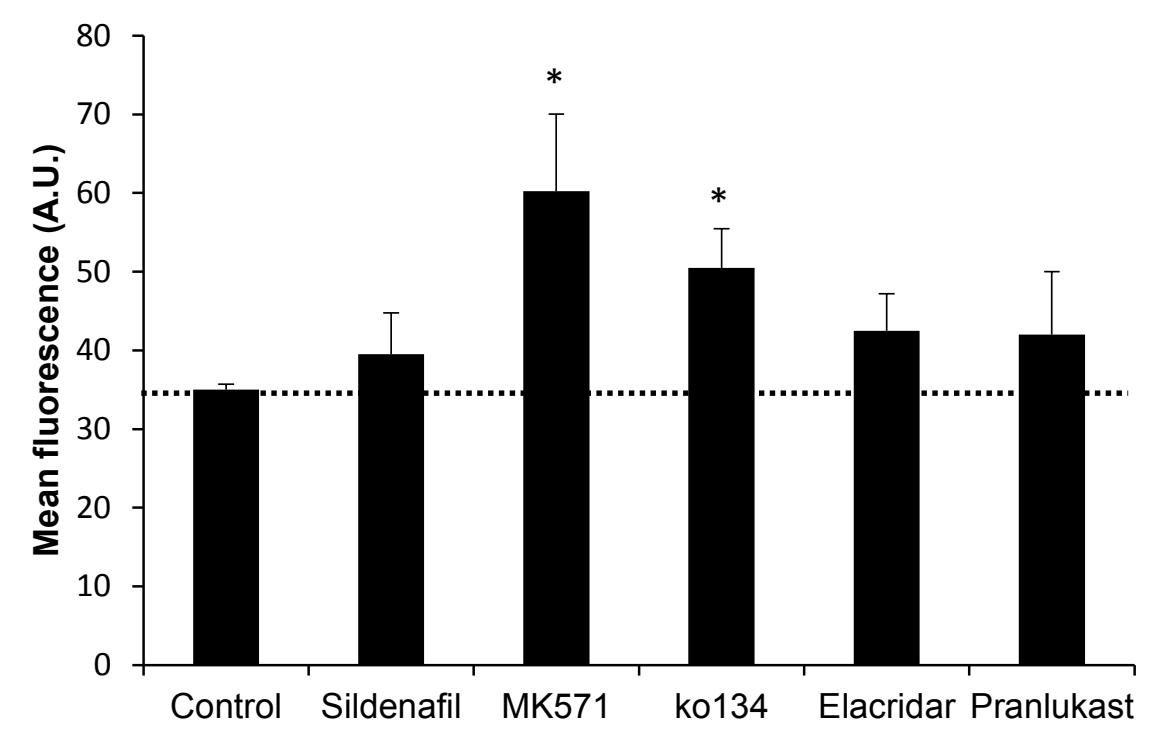

(b)

\section{Bodipy prazosin}

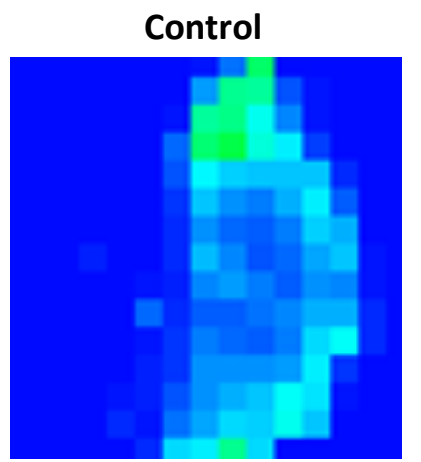

MK571

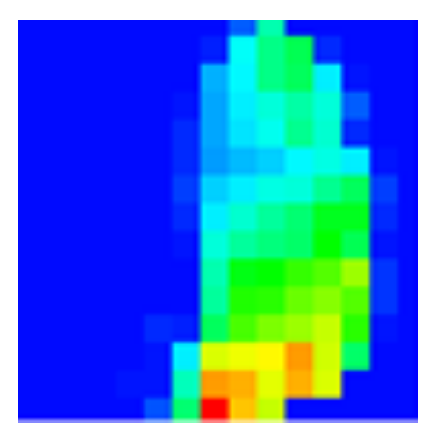

Pheoporbide A

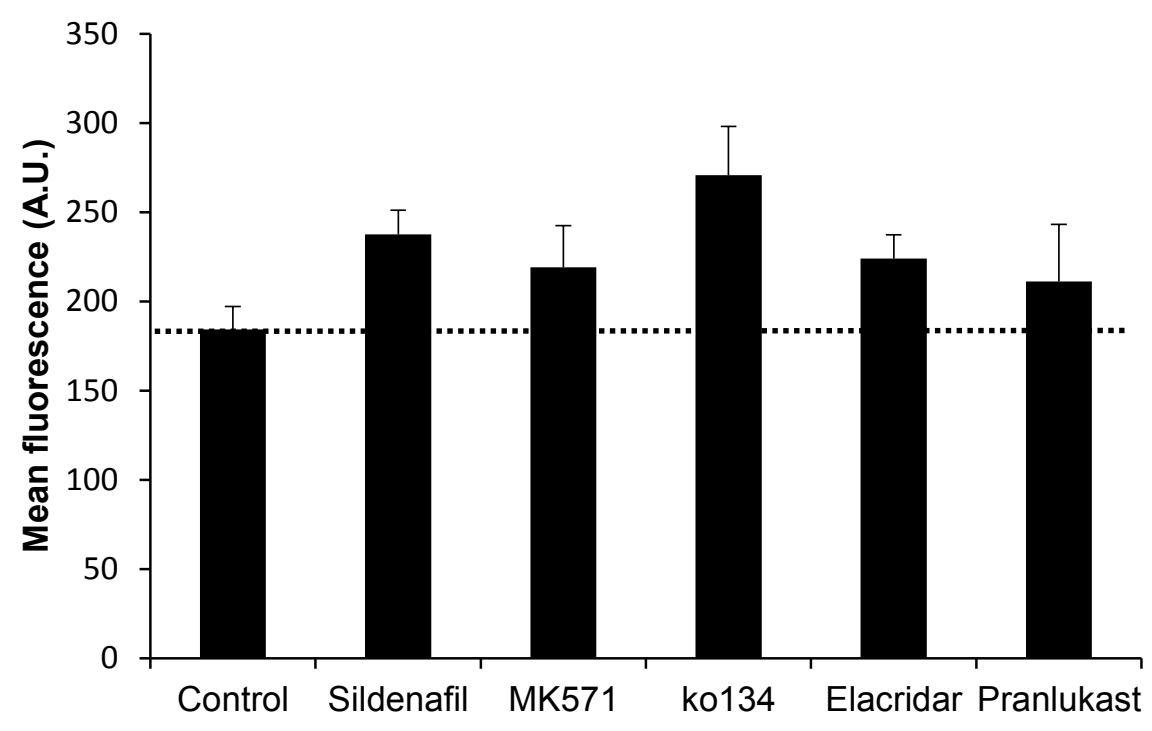

Pheoporbide A
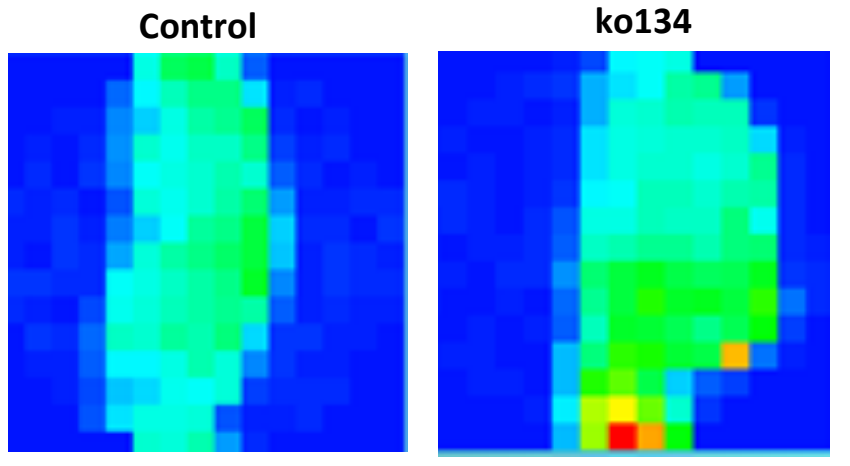
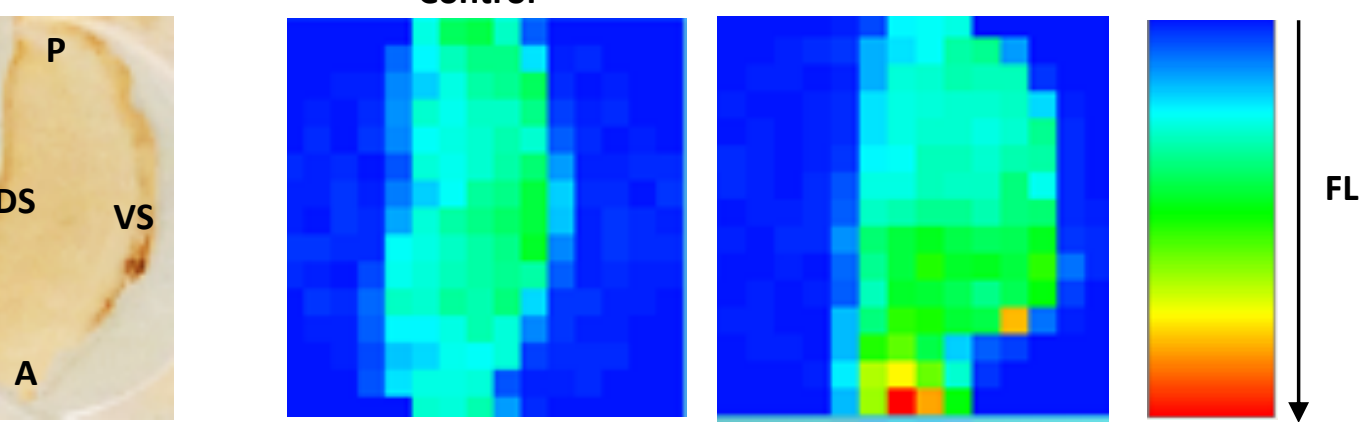